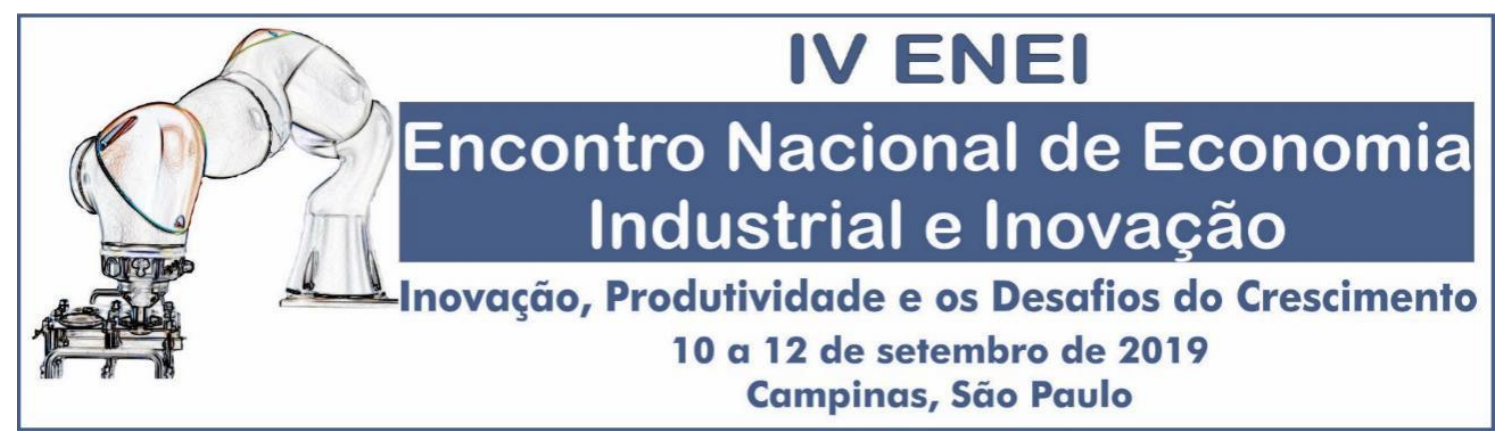

\title{
A especialização geográfica e setorial das exportações brasileiras segundo o comércio em valor adicionado
}

\author{
Marta Castilho (IE-UFRJ e ICEI-UCM) \\ Leonardo Thuler Costa (IE-UFRJ) \\ Kaio Vital da Costa (IE-UFRJ)
}

Resumo

Esse trabalho busca aprofundar a análise da inserção do Brasil nas chamadas Cadeias Globais de Valor ao aplicar a metodologia de decomposição das exportações brutas proposta por Wang, Wei e Zhu (2014, 2018). Tal metodologia decompõe as exportações brutas desagregadas geograficamente e setorialmente em diversos componentes que possibilitam identificar de uma melhor forma os fluxos de valor adicionado doméstico e estrangeiro das exportações e, assim, aprofundar a caracterização da integração dos países nas CGV. Usando-se os dados da base WIOD para o período 2000-2014, a inserção do Brasil nas CGV é examinada em uma perspectiva comparada com países selecionados e, em seguida, analisase a intensidade e o perfil da especialização comercial brasileiras para as exportações em valor adicionado para três dos seus principais parceiros comerciais (China, EUA e UE). A avaliação do perfil das exportações desagregadas geográfica e setorialmente é de particular interesse para o Brasil pois a especialização comercial do país difere de forma significativa segundo os seus parceiros.

Palavras-chave: Cadeias Globais de Valor; Fragmentação internacional da produção; Comércio em valor adicionado; Brasil; parceiros comerciais

Área temática ABEIN: 2.2 - Comércio internacional e cadeias de valor

Abstract:

This paper deepens the analysis of the insertion of Brazil into the so-called Global Value Chains by applying the decomposition methodology of gross exports proposed by Wang, Wei and Zhu (2014, 2018). Such methodology decomposes disaggregated gross exports into several components making it possible to measure the domestic and foreign value added embedded in bilateral and sectoral exports and, thus, to characterize more accurately the participation of countries into CGV. Using data from the WIOD database for the period 2000-2014, we examine, first, the Brazilian insertion into CGVs in an international comparative perspective and, secondly, the Brazilian specialization for exports in value for three of its main trading partners (China, US and EU). The analysis of the geographical and sectoral exports profile is of interest to Brazil since the country's commercial specialization differs significantly according to its partners.

Keywords: Global Value Chains; Trade in Value Added; Brazil; trade partners

JEL Classification: F1, F14, L14 


\section{A especialização geográfica e setorial das exportações brasileiras segundo o comércio em valor adicionado}

\section{Introdução}

A fragmentação internacional dos processos de produção tem desafiado a capacidade das estatísticas comerciais tradicionais em representar verdadeiramente os elos de oferta e demanda entre as economias. Em geral, as exportações bilaterais diferem da parte do PIB de um país relacionada com a produção de bens e serviços enviados para determinado mercado de destino. Por um lado, as exportações também incorporam insumos intermediários importados, mas, por outro lado, o país importador direto frequentemente difere do destino final no qual o bem é absorvido pela demanda final. Sempre que a produção é organizada em etapas sequenciais de processamento em diferentes países, as estatísticas tradicionais são incapazes de separar adequadamente a contribuição de cada país em termos de valor adicionado doméstico e estrangeiro incorporado aos bens e serviços. A formação de cadeias globais e regionais de valor (CGV) aprofundou a divergência entre os fluxos brutos, conforme registrado pelas estatísticas tradicionais de comércio, e os dados sobre produção e demanda final contabilizados em estatísticas baseadas no valor adicionado.

Koopman, Wang e Wei (2014) (doravante KWW) propõem uma ampla decomposição do total das exportações brutas, que preenche a lacuna entre as estatísticas oficiais de comércio bruto e o Sistema de Contas Nacionais. Este não é o primeiro esquema a classificar os fluxos de comércio pela origem e pelo destino de seu valor adicionado, mas sua estrutura abrange a maioria das metodologias propostas na literatura (Hummels, Ishii e Yi, 2001; Daudin, Rifflart e Schweisguth, 2009; Johnson e Noguera, 2012). KWW salientam que diferentes esquemas de fragmentação internacional da produção produzem diferentes proporções de conteúdo de valor adicionado nas exportações brutas. Em particular, eles mostram que nem todos os fluxos contados em duplicidade nas estatísticas de comércio bruto são iguais. Além disso, em consonância com o estudo de Johnson e Noguera (2012), eles classificam o valor adicionado nas exportações de modo a levar em conta também o destino da absorção final.

A possibilidade de fragmentar a produção e localizá-la em diferentes países dispersos geograficamente levou a mudanças na composição dos fluxos de comércio mundial em dois principais aspectos: o maior crescimento do comércio em bens intermediários vis-à-vis o comércio em bens finais (Lund et al., 2019), o que, por sua vez, possibilitou a produção de bens e serviços de forma fragmentada em diversos países, alterando a geografia da produção e do comércio mundial. Com respeito a este ponto, por um lado, a distribuição das atividades manufatureiras mostrou um deslocamento principalmente para a região asiática, e, por outro lado, as atividades produtivas, inclusive manufatureira, apresentaram uma tendência à regionalização. Desde a década de 1980 observou-se a formação de redes com forte caráter regional (ainda que conectadas internacionalmente), localizadas na América do Norte, Europa e Ásia, possibilitando a formação do que foi denominado de "três fabricas mundiais". ${ }^{1}$

As mudanças na organização do processo produtivo requereram reflexões acerca da mensuração do comércio e da produção, no sentido de distinguir a parcela do valor dos produtos e serviços geradas no exterior. Em outras palavras, a fragmentação do processo produtivo, ao distribuir etapas do processo produtivo em diferentes regiões e países, aumentou a distância entre o valor bruto das mercadorias e o valor adicionado doméstico, relativamente a uma organização de produção anterior mais verticalizada. Isso é particularmente relevante para a avaliação do grau de internacionalização das economias, assim como para a compreensão da contribuição do comércio exterior para a economia doméstica, em termos de renda, emprego e dinamismo econômico. Ou seja, são particularmente relevantes para avaliação das questões relacionadas ao desenvolvimento socioeconômico dos países.

Muito se avançou na caracterização e análise das CGV e das redes de produção e comércio internacionais. A emergência destas cadeias, cujas origens encontram-se em fatores tecnológicos, institucionais e geopolíticos, suscitou o uso de diversos instrumentos de análise. O desenvolvimento de matrizes de insumo-produto globais permitiu o avanço do mapeamento das cadeias e tem permitido a

\footnotetext{
${ }^{1}$ Ver Baldwin (2017) e Lund et al. (2019).
} 
compreensão de sua configuração e principais características. Elas evidenciam a interação entre os parques produtivos dos países e possibilitam, em última instância, a avaliação de como a inserção dos países nas referidas redes afetam o desenvolvimento socioeconômico deles.

O presente artigo analisa a inserção comercial brasileira no contexto de fragmentação internacional da produção. Diversos estudos (Hermida e Xavier, 2018, Marcato et al., 2019, Ferraz et al., 2015) analisaram a inserção do Brasil nas CGV. O presente artigo pretende aprofundar uma dimensão já analisada em termos de valor bruto do comércio (Castilho, Costa e Torracca, 2019), porém pouco explorada do ponto de vista do comércio em valor adicionado - qual seja, a diferente especialização das exportações brasileiras segundo os seus parceiros. No entanto, estudos sobre a participação de países latino-americanos nas cadeias de valor foram dificultados pela disponibilidade limitada de dados. Embora as estatísticas comerciais convencionais (ou seja, em termos de valores brutos) em bens intermediários (ou em partes e componentes, como em Lemoine e Unal-Kesenci, 2004) são utilizados na literatura empírica como um proxy para o comércio de GVC, eles não fornecem um quadro detalhado das interrelações entre os setores produtores de bens intermediários e aqueles que os utilizam em seu processo de produção. $\mathrm{O}$ uso de tabelas multipaíses de insumo-produto permite uma identificação mais precisa das ligações internacionais de produção.

Por ser um país de nível médio de desenvolvimento, o Brasil apresenta perfis distintos de comércio com seus diferentes parceiros. As diferenças de nível de desenvolvimento dos países justificam a diferença de uma especialização do tipo Norte-Sul com Europa e Japão relativamente àquela observada com os países da América Latina e mesmo África, para os quais o Brasil apresenta uma pauta de exportações mais sofisticada e com maior peso de produtos manufaturados. Porém, não é apenas o nível de desenvolvimento que explica tais diferenças, a distância geográfica aparece como outro fator explicativo que contribui para a compreensão de tal fenômeno. Dentre os países desenvolvidos, por exemplo, o perfil das exportações para os EUA difere daquele para UE e Japão. Quando analisamos o comércio bilateral com a China, o Brasil apresenta um perfil que poderia ser caracterizado como NorteSul, isto é, exportando commodities agrícolas e industriais e importando manufaturas. O presente artigo realiza uma contribuição à literatura de inserção comercial do Brasil e de cadeias de valor a partir da utilização da metodologia de WANG, WEI e ZHU (2014, 2018, doravante WWZ), que permite um aprofundamento da caracterização dos fluxos de comércio em valor adicionado desagregada por setor e por parceiro.

A metodologia utilizada corresponde à decomposição das exportações brutas proposta por WWZ $(2014,2018)$, que avança relativamente ao estudo realizado por Koopman, Wang e Wei [KWW] $(2010,2014)$ para fluxos agregados setorial e geograficamente. Tal procedimento permite identificar, de forma detalhada, os diversos componentes das exportações, distinguindo quais as parcelas de valor adicionado pelo Brasil, pelos seus parceiros comerciais e qual parcela é dupla contagem. Desta forma, permite uma avaliação mais acurada do tipo de comércio - em especial, se as exportações denotam a participação do Brasil em redes de produção e comercio envolvendo seus parceiros.

A disponibilidade de dados levou a escolha dos parceiros analisados no presente artigo, que são China, EUA e UE. Este grupo de países respondem por cerca de $45 \%$ das exportações brutas brasileiras em 2014. Lamentavelmente, a base de dados WIOD, utilizada aqui, não dispõe dos dados para países da América Latina que são de grande interesse devido ao peso para as exportações brasileiras e ao particular perfil do comercio regional.

O artigo está organizado da seguinte forma. Além desta introdução, a metodologia utilizada é apresentada, discutindo a evolução recente das diversas ferramentas metodológicas. Nas duas seções seguintes são apresentados os resultados das decomposições. A terceira seção se dedica as exportações brasileiras totais e contem inicialmente uma comparação com países selecionados, para terminar com a decomposição setorial das exportações brasileiras. A quarta seção se dedica a análise da decomposição das exportações brasileiras para três de seus principais parceiros, tanto para o conjunto de setores quanto para as exportações desagregadas setorialmente. As diferenças na intensidade e no padrão de envolvimento do Brasil nas CGV e discutido nas conclusões. 


\section{Metodologia}

As exportações de determinado país são frequentemente consideradas como uma proxy para a demanda externa, mas os fluxos de comércio bruto fornecem apenas uma imagem aproximada desses fluxos. Em um contexto de CGV, alguns produtos são exportados apenas para processamento no exterior e depois reimportados para suprir a demanda doméstica. Tais exportações, claramente, não são geradas pela demanda externa. Em outros casos, mesmo quando a mercadoria final é consumida no exterior, o país de absorção final pode ser diferente do importador original. Usando tabelas de insumo-produto entre países como as elaboradas pelo projeto WIOD (Timmer et al. 2015) ou o OECD-WTO TiVA, podemos rastrear o valor adicionado ao longo da cadeia de valor desde a origem até o país de uso final. Essas bases permitem avaliar melhor o papel da demanda externa, distinguindo as exportações intermediárias para uso final doméstico daquelas absorvidas no exterior, e identificando os mercados finais para insumos exportados. A partir da metodologia proposta por $\mathrm{KWW}(2014,2018)$ para a decomposição exportações brutas, é possível explorar os dados nessas tabelas internacionais de insumo-produto para relacionar o país de origem com aquele no qual o valor adicionado é finalmente absorvido.

A análise dos fluxos internacionais de comércio tradicionalmente baseia-se em dados brutos de comércio. Contudo, com o surgimento e aprofundamento do fenômeno da fragmentação mundial da produção e das CGV, a utilização de indicadores baseados nas estatísticas de comércio em valores brutos tornou-se inadequada por incluir a múltipla contagem dos bens intermediários, que atravessam várias vezes as fronteiras de um mesmo país. À título de ilustração, a UNCTAD (2013) estima que 28\% do comércio mundial no ano de 2010 correspondia à "dupla contagem" referente ao valor adicionado estrangeiro presente nas exportações. Por conta desse problema estatístico, tem sido constante a busca por metodologias capazes de eliminá-lo e crescente o uso das estatísticas de comércio em valor adicionado (ou valor adicionado do comércio). Portanto, a tentativa de se distinguir a parte do valor do comércio adicionada no país ou no exterior tornou-se um tema central para a compreensão da inserção internacional dos países e de suas possibilidades de desenvolvimento.

KWW $(2010,2014)$ propõem uma medida de especialização vertical que corresponde ao valor dos bens importados utilizados como insumos nas exportações de um país, o que indica a especialização vertical pelo lado das importações. Os autores reconhecem, porém, que a integração vertical ocorre também pelo lado das exportações e propõem então uma medida que corresponde a quanto o mundo está utilizando de insumos do país em questão para produzir as suas exportações. Entretanto, devido a limitações dos dados, os autores não conseguem calcular essa medida. ${ }^{2}$

Seguindo esse raciocínio, KWW dividem as exportações brutas em diferentes componentes do valor adicionado interno e externo, além de dois itens de contagem dupla "pura". Quanto aos últimos, eles mostram que as exportações brutas não consistem, em geral, apenas em valor adicionado que pode ser rastreado até o PIB gerado domesticamente ou no exterior. Em vez disso, alguns fluxos de comércio são contados duas vezes, como quando os insumos intermediários cruzam as fronteiras de um país várias vezes de acordo com os diferentes estágios de produção. Vale notar que os itens de contagem dupla são cada vez mais importantes nos fluxos de comércio internacional, como apontam Wang et al. (2014) e Cappariello e Felettigh (2015). Esse é um dos motivos pelos quais pode ser útil adotar a abordagem KWW na análise dos fluxos de comércio bilateral.

A decomposição das exportações brutas propostas por KWW $(2010,2014)$ distingue três grupos - o valor adicionado doméstico exportado, o valor adicionado doméstico que retorna ao país e o valor estrangeiro exportado - que podem ser desagregados em nove componentes, conforme o esquema da Figura 1. Em cada um dos 3 grupos, estão bens que são incorporados a bens finais ou intermediários, sendo que estes podem ser consumidos no país de destino ou incorporados às suas exportações. Tal

\footnotetext{
${ }^{2}$ Daudin et al (2009), além das medidas de especialização vertical propostas por HYI (2001), propõem uma medida que identifica a parte do valor adicionado exportado que retorna para o país de origem.
} 
desagregação permite identificar a parte das exportações brutas que contribui para o PIB, qual é a parcela de dupla contagem, qual é a parcela de conteúdo importado contido nas exportações, além de possibilitar estimar com certa fidedignidade o quanto os países estão envolvidos nas CGV. No presente estudo, optou-se por apresentar rapidamente a metodologia de KWW e privilegiar a apresentação da proposta metodológica de WWZ (2014, 2018), que consiste em uma desagregação do primeiro e atende melhor ao objetivo de análise da especialização setorial e geográfica das exportações brasileiras.

Figura 1 - Componentes da decomposição das exportações brutas por Koopman et al $(2010,2014)$

Exportações brutas

\begin{tabular}{|c|c|c|c|c|c|c|c|c|}
\hline \multicolumn{3}{|c|}{$\begin{array}{c}\text { Valor adicionado doméstico } \\
\text { exportado (VT) }\end{array}$} & \multicolumn{3}{|c|}{$\begin{array}{l}\text { VA doméstico que retorna ao país } \\
\qquad\left(\mathrm{VS} 1^{*}\right)\end{array}$} & \multicolumn{3}{|c|}{ Valor estrangeiro exportado (VS) } \\
\hline $\begin{array}{c}\text { VA } \\
\text { doméstico } \\
\text { exportado } \\
\text { via } \\
\text { produtos } \\
\text { finais }\end{array}$ & \begin{tabular}{|c|} 
VA \\
doméstico \\
exportado \\
via bens \\
interme- \\
diários \\
absorvidos \\
pelo \\
importa- \\
dor direto
\end{tabular} & \begin{tabular}{|c|} 
VA \\
doméstico \\
exportado \\
via bens \\
interme- \\
diários \\
reexpor- \\
tados \\
para \\
terceiros \\
países
\end{tabular} & \begin{tabular}{|c|} 
VA \\
doméstico \\
que \\
retorna \\
via bens \\
finais
\end{tabular} & \begin{tabular}{|c} 
VA \\
doméstico \\
que \\
retorna \\
via bens \\
interme- \\
diários
\end{tabular} & \begin{tabular}{|c|} 
Pura \\
dupla \\
contagem \\
do VA \\
doméstico
\end{tabular} & \begin{tabular}{|} 
VA estran- \\
geiro \\
exportado \\
via bens \\
finais
\end{tabular} & $\begin{array}{l}\text { VA estran- } \\
\text { geiro } \\
\text { exportado } \\
\text { via bens } \\
\text { interme- } \\
\text { diários }\end{array}$ & $\begin{array}{l}\text { Pura } \\
\text { dupla } \\
\text { contagem } \\
\text { do VA } \\
\text { estran- } \\
\text { geiro }\end{array}$ \\
\hline
\end{tabular}

Notas: As siglas entre parênteses indicam a correspondência com as variáveis propostas por Hummels et al (2001). Fonte: Elaboração própria a partir de Koopman et al (2014).

A proposta metodológica de WWZ $(2014,2018)$ desagrega ainda mais as exportações brutas em 16 componentes - e permite decompor as exportações setorial e/ou geograficamente. Além da importância para a análise da especialização dos países, este tipo de cálculo é fundamental para a compreensão do caráter regional das cadeias de valor e para a análise da integração produtiva dos países.

Para trabalhar com esses níveis de desagregação bilateral e setorial, os autores realizam uma distinção entre duas medidas de valor adicionado doméstico contido nas exportações. A primeira é baseada em ligações industriais "para trás" (ou backward industrial linkages) e decompõe as exportações de valor adicionado por origem (doméstica ou estrangeira). A segunda é baseada em ligações industriais "para frente" (forward industrial linkages) ${ }^{3}$ e decompõe o valor adicionado doméstico por setor de acordo com o lugar no qual é utilizado. A distinção é necessária, pois a esse nível de desagregação das exportações brutas, essas medidas têm significados econômicos distintos.

Na decomposição das exportações em valor adicionado dos bens intermediários, WWZ (2014, 2018) realizam dois procedimentos metodológicos. O primeiro é decompor as exportações de insumos intermediários do país de acordo com o local no qual são consumidas. O segundo procedimento é decompor as exportações de insumos intermediários segundo como são utilizadas pelos importadores diretos, se em vendas domésticas ou exportações.

O valor adicionado presente nas exportações de um país pode ser dividido nas parcelas de valor adicionado doméstico e estrangeiro. Assim, ao aplicar a decomposição de Leontief às exportações de bens finais de um país temos as participações do valor adicionado doméstico e do estrangeiro. Para as exportações de bens intermediários, também se aplica a decomposição para identificar as participações do valor adicionado doméstico e estrangeiro. Nesse caso, utiliza-se também o multiplicador doméstico do valor adicionado (similar ao modelo insumo-produto de apenas um país), o qual significa o valor

\footnotetext{
${ }^{3}$ Ao nível agregado de um país, como feito por Koopman et al $(2010,2014)$ a decomposição não precisa demonstrar essa distinção, como mostrado por WWZ (2018) no apêndice F.
} 
adicionado doméstico gerado pelo aumento na demanda em uma unidade de produto doméstico, sem influências estrangeiras.

De acordo com WWZ (2018), as exportações brutas de um país s para um r, no nível setorial podem ser divididas em dezesseis termos, conforme a equação abaixo. Os cinco primeiros componentes representam o valor adicionado doméstico das exportações de um setor do país s para o país $\mathrm{r}$ que é consumido no exterior (VAX_G). Já o valor adicionado doméstico contido nas exportações do setor de um país que retorna ao país de origem (RDV_G) contém três termos da decomposição ao nível setorial (do sexto ao oitavo termo). Já o valor adicionado estrangeiro contido nas exportações de um setor do país $s$ para o país $r\left(V S_{S}\right)$ corresponde aos componentes (9) ao (16). O Quadro 1 explica o significado de cada termo.

$$
\begin{aligned}
& E^{s r}=\underbrace{\left(V^{S} B^{s r}\right)^{T} \# Y^{s r}}_{\left(1-D V A_{-} F I N\right)}+\underbrace{\left(V^{S} L^{S S}\right)^{T} \#\left(A^{s r} B^{r r} Y^{r r}\right)}_{\left(2-D V A_{-} I N T\right)}+ \\
& \underbrace{\left(V^{S} L^{S S}\right)^{T} \# A^{s r} \sum_{t \neq s, r}^{G} B^{r t} Y^{t t}}_{\left(3-D V A \_I N T r e x I 1\right)}+\underbrace{\left(V^{S} L^{S S}\right)^{T} \# A^{s r} B^{r r} \sum_{t \neq s, r}^{G} Y^{r t}}_{\left(4-D V A_{-} I N T r e x F\right)}+ \\
& \underbrace{\left(V^{s} L^{S S}\right)^{T} \# A^{s r} \sum_{t \neq s, r}^{G} B^{r t} \sum_{u \neq s, t}^{G} Y^{t u}}_{\left(5-D V A_{-} I N T r e x I 2\right)}+\underbrace{\left(V^{s} L^{s S}\right)^{T} \# A^{s r} B^{r s} Y^{s S}}_{\left(6-R D V_{-} I N T\right)}+ \\
& \underbrace{\left(V^{s} L^{S S}\right)^{T} \# A^{s r} B^{r r} Y^{r s}}_{\left(7-R D V_{-} F I N\right)}+\underbrace{\left(V^{s} L^{s s}\right)^{T} \# A^{s r} \sum_{t \neq s, r}^{G} B^{r t} Y^{t s}}_{\left(8-R D V_{-} F I N 2\right)}+\underbrace{\left(V^{s} L^{s s}\right)^{T} \#\left(A^{s r} B^{r s} \sum_{t \neq s}^{G} Y^{s t}\right)}_{\left(9-D D C_{-} F I N\right)}+ \\
& \underbrace{\left(V^{s} L^{s s} \sum_{t \neq s}^{G} A^{s t} B^{t s}\right)^{T} \#\left(A^{s r} X^{r}\right)}_{\left(10-D D C_{-} I N T\right)}+\underbrace{\left[\sum_{t \neq s, r}^{G} V^{t} B^{t s}\right]^{T} \# Y^{s r}}_{(11-\text { OVA_FIN })}+\underbrace{\left(V^{r} B^{r s}\right)^{T} \# Y^{s r}}_{\left(12-M V A_{-} F I N\right)}+\underbrace{\left[\sum_{t \neq s, r}^{G} V^{t} B^{t s}\right]^{T} \#\left(A^{s r} L^{r r} Y^{r r}\right)}_{\left(13-O V A_{-} I N T\right)}+ \\
& \underbrace{\left(V^{r} B^{r s}\right)^{T} \#\left(A^{s r} L^{r r} Y^{r r}\right)}_{\left(14-M V A_{-} I N T\right)}+\underbrace{\left[\sum_{t \neq s, r}^{G} V^{t} B^{t s}\right]^{T} \#\left(A^{s r} L^{r r} E^{r^{*}}\right)}_{(15-O D C)}+\underbrace{\left(V^{r} B^{r s}\right)^{T} \#\left(A^{s r} L^{r r} E^{r^{*}}\right)}_{(16-M D C)}
\end{aligned}
$$

Onde $V^{s}$ é a parcela de valor adicionado das exportações de um setor do país s para o país r; $B^{s r}$ são os requerimentos diretos e indiretos da produção do país s que são necessários devido ao aumento da demanda final em uma unidade no país $\mathrm{r}$ (analogamente para $B^{r r}$ e $B^{r t}$ ); $Y^{s r}$ representa os bens finais produzidos no país s e consumidos no país r (o mesmo para $Y^{r r}, Y^{t t}, Y^{r t}$ e $Y^{t u}$ ); $A_{s r}$ é a matriz de coeficientes técnicos de produção do país s para o país $\mathrm{r}$ e $L^{S S}$ representa a matriz inversa de Leontief nacional. Logo, $V^{s} L^{s s}$ é o multiplicador do valor adicionado doméstico.

A soma dos termos (9), (10), (15) e (16) representa toda a dupla contagem (doméstica e estrangeira) incorporada nas exportações brutas do país s (chamada de PDC). Parte dela - termos (9) e (10) - representa a dupla-contagem do valor adicionado doméstico devido às múltiplas vezes que um produto atravessa as fronteiras do país (DDC). ${ }^{4}$ Os demais itens- termos (15) e (16) - correspondem a dupla-contagem total do valor adicionado estrangeiro nas exportações do país (FDC).

\footnotetext{
${ }^{4}$ Nesse ponto, é importante ressaltar uma diferença entre a classificação do VS para KWW (2010, 2014) e WWZ (2014, 2018). Para o primeiro, o DDC compõe as exportações domésticas de valor adicionado que retorna ao país de origem (VS1*), enquanto que para o segundo, o DDC é parte do VS.
} 


\begin{tabular}{|c|c|c|}
\hline Equações & & Descrição \\
\hline$\left(V^{s} B^{s r}\right)^{T} \# Y^{s r}$ & DVA_FIN & $\begin{array}{l}\text { VA doméstico exportado via bens finais pelo pais } s \text { e absorvidos no importador } \\
\text { direto } r\end{array}$ \\
\hline$\left(V^{s} L^{S S}\right)^{T} \#\left(A^{s r} B^{r r} Y^{r r}\right)$ & DVA_INT & $\begin{array}{l}\text { VA doméstico exportado via bens intermediários pelo pais } s \text { e absorvidos no } \\
\text { importador direto } r\end{array}$ \\
\hline$\left(V^{s} L^{S S}\right)^{T} \# A^{s r} \sum_{t \neq s, r}^{G} B^{r t} Y^{t t}$ & $\begin{array}{l}\text { DVA } \\
\text { INTrex } 1\end{array}$ & $\begin{array}{l}\text { VA doméstico contido nas exportações de bens intermediários que são } \\
\text { reexportados pelo importador direto, como bens intermediários, para terceiros } \\
\text { países que os utilizam na produção de bens finais por eles consumidos. }\end{array}$ \\
\hline$\left(V^{s} L^{s s}\right)^{T} \# A^{s r} B^{r r} \sum_{t \neq s, r}^{G} Y^{r t}$ & $\begin{array}{c}\text { DVA_ } \\
\text { INTrex2 }\end{array}$ & $\begin{array}{l}\text { Valor adicionado doméstico exportado via intermediários utilizados pelo } \\
\text { importador direto para produzir exportações de bens finais para terceiros países. }\end{array}$ \\
\hline$\left(V^{s} L^{S S}\right)^{T} \# A^{s r} \sum_{t \neq s, r}^{G} B^{r t} \sum_{u \neq s, t}^{G} Y^{t u}$ & $\begin{array}{l}\text { DVA_ } \\
\text { INTrex3 }\end{array}$ & $\begin{array}{l}\text { VA doméstico exportado via bens intermediários, reexportados pelo importador } \\
\text { direto como bens intermediários a serem utilizados por terceiros países na } \\
\text { produção de suas exportações (exceto aquelas que retornam ao país } s \text { de origem). }\end{array}$ \\
\hline$\left(V^{s} L^{s S}\right)^{T} \# A^{s r} B^{r r} Y^{r s}$ & RDV_INT & $\begin{array}{l}\text { VA doméstico exportado como bens intermediários de um setor do país s para o } \\
\text { país r, que retorna ao país s (de origem) em forma de bens intermediários para a } \\
\text { produção e consumo de bens finais no país de origem. }\end{array}$ \\
\hline$\left(V^{s} L^{S S}\right)^{T} \# A^{s r} \sum_{t \neq s, r}^{G} B^{r t} Y^{t s}$ & RDV_FIN & $\begin{array}{l}\text { Valor adicionado doméstico exportado como bens intermediários que retorna ao } \\
\text { país de origem como bens finais via importações originadas no importador direto } r \text {. }\end{array}$ \\
\hline$\left(V^{s} L^{s s}\right)^{T} \# A^{s r} B^{r s} Y^{s s}$ & RDV_FIN2 & $\begin{array}{l}\text { VA doméstico exportado como bens intermediários que retorna ao país de origem } \\
\text { como bens finais via importações de bens finais originadas em terceiros países. }\end{array}$ \\
\hline$\left(V^{s} L^{s S}\right)^{T} \#\left(A^{s r} B^{r s} \sum_{t \neq s}^{G} Y^{s t}\right)$ & DDC_FIN & $\begin{array}{l}\text { Pura dupla contagem de valor adicionado doméstico contido nas (re)exportações de } \\
\text { bens finais. }\end{array}$ \\
\hline$\left(V^{s} L^{S S} \sum_{t \neq s}^{G} A^{s t} B^{t s}\right)^{T} \#\left(A^{s r} X^{r}\right)$ & DDC_INT & $\begin{array}{l}\text { Pura dupla contagem de valor adicionado doméstico nas nas (re)exportações do } \\
\text { país de origem em bens intermediários. }\end{array}$ \\
\hline$\left(V^{r} B^{r s}\right)^{T} \# Y^{s r}$ & OVA_FIN & $\begin{array}{l}\text { Valor adicionado estrangeiro de terceiros países nas exportações de bens finais do } \\
\text { pais s. }\end{array}$ \\
\hline$\left[\sum_{t \neq s, r}^{G} V^{t} B^{t s}\right]^{T} \# Y^{s r}$ & MVA_FIN & $\begin{array}{l}\text { VA estrangeiro do importador direto (país r) contido nas exportações de bens finais } \\
\text { de um setor do país s para o r. }\end{array}$ \\
\hline$\left(V^{r} B^{r s}\right)^{T} \#\left(A^{s r} L^{r r} Y^{r r}\right)$ & OVA_INT & $\begin{array}{l}\text { Valor adicionado estrangeiro de países terceiros nas exportações de bens } \\
\text { intermediários do país s. }\end{array}$ \\
\hline$\left[\sum_{t \neq s, r}^{G} V^{t} B^{t s}\right]^{T} \#\left(A^{s r} L^{r r} Y^{r r}\right)$ & MVA_INT & $\begin{array}{l}\text { Valor adicionado estrangeiro do importador direto (r) nas exportações de bens } \\
\text { intermediários do pais s. }\end{array}$ \\
\hline$\left(V^{r} B^{r s}\right)^{T} \#\left(A^{s r} L^{r r} E^{r^{*}}\right)$ & ODC & $\begin{array}{l}\text { Valor adicionado estrangeiro de terceiros países contido nas exportações do país s } \\
\text { para que aqueles países produzam suas exportações - dupla contagem de valor } \\
\text { adicionado estrangeiro de terceiros países. }\end{array}$ \\
\hline$\left[\sum_{t \neq s, r}^{G} V^{t} B^{t s}\right]^{T} \#\left(A^{s r} L\right.$ & MDC & $\begin{array}{l}\text { Valor adicionado estrangeiro do importador direto (país r) contido nas exportações } \\
\text { de um setor do país s para o r - Pura dupla contagem de valor adicionado } \\
\text { estrangeiro do importador direto. }\end{array}$ \\
\hline
\end{tabular}

Fonte: Elaboração própria a partir de Wang, Wei e Zhu (2018).

Para a análise da inserção brasileira nas CGV, escolheu-se utilizar a base de dados proveniente da World Input-Output Database (WIOD). ${ }^{5}$ Os dados da WIOD são originados nas tabelas de usos e recursos oficiais e, portanto, são compatíveis com as Contas Nacionais e com os dados de comércio internacional (Timmer et al., 2015). Sobre o comercio de serviços, a WIOD contém uma cobertura detalhada dos fluxos bilaterais. Como não existe uma base de dados padronizada para tais fluxos, os dados foram coletados de diversas fontes e integrados para formar uma base de dados de comércio bilateral de serviços, tendo sido testados para verificar a consistência entre eles.

A versão da WIOD utilizada (2016) possui dados entre 2000 e $2014^{6}$ e inclui 43 países ${ }^{7}$, além de uma estimação para o resto do mundo. Os dados são organizados em três categorias de uso (investimento,

\footnotetext{
${ }^{5} \mathrm{O}$ estudo utiliza os dados a preços correntes.

${ }^{6}$ A duas bases disponíveis da WIOD (versão 2013 e 2016) são incompatíveis dadas as diferentes agregações utilizadas em cada caso.

${ }^{7}$ A base inclui os 28 países da UE, além de 15 outras economias (Austrália, Brasil, Canada, China, Índia, Indonésia, Japão, México, Noruega, Rússia, Coreia, Suíça, Taiwan, Turquia e EUA). Infelizmente, a cobertura para a América do Sul, onde estão alguns sócios comerciais importantes para o Brasil, e baixa.
} 
intermediários e consumo final) e seguem uma compatibilização entre o Harmonized System (HS) e a BEC. São 56 setores baseados na classificação International Standard Industrial Classification - REV 4 (ISIC). Os dados de comércio bilateral são retirados da base de dados das Nações Unidas COMTRADE ${ }^{8}$.

Uma limitação da base - não somente da WIOD - surge do tratamento limitado de países caracterizados como plataformas processadoras de exportações, como o México, por exemplo. Nesse caso, os insumos importados, em geral, têm maior peso quando considerada a produção para a exportação em relação à produção destinada para atender o mercado doméstico. Com isso, a falta de aplicação de coeficientes técnicos de produção diferenciados para os dois casos pode subestimar o papel dos insumos domésticos na produção das exportações.

Outra limitação é colocada por Timmer et al. (2012): a aceitação implícita da hipótese de proporcionalidade das importações implica em uma a mesma taxa de importação para o produto independentemente de seu uso (final ou intermediário, por exemplo). Apesar da base WIOD ter realizado avanços em relação à hipótese da proporcionalidade das importações, com a utilização das tabelas de usos e destinos de comércio bilateral para derivar a parcela das importações de acordo o uso intermediário, consumo final ou investimento, ela ainda sofre com essa hipótese dentro de cada um dos três tipos de uso dos produtos, agora com uma maior desagregação.

A análise dos resultados da decomposição de $\operatorname{WWZ}(2014,2018)$ será feita em diversas etapas. Primeiro, compara-se as exportações totais do Brasil com alguns parceiros selecionados (EUA, UE, México, China, Rússia, Índia, Japão e Coreia do Sul) a fim de se ter uma referência para as análises desagregadas que seguem. Em seguida, é feita uma análise das exportações setoriais totais do Brasil. Por fim, análises da decomposição para fluxos totais e setoriais são conduzidas para as exportações brasileiras para três dos seus principais parceiros comerciais: EUA, União Europeia e China. Uma limitação da base de dados para análises brasileiras é não incorporar mais países latino-americanos, nomeadamente os países do MERCOSUL. Os anos selecionados para a análise são 2000 e 2014. Os setores são agregados em cinco grandes setores (agricultura, mineração, indústria de transformação/manufatura, serviços e outros serviços).

\section{Perfil geográfico das exportações brasileiras}

A análise dos componentes propostos pela decomposição de $\operatorname{WWZ}(2014,2018)$ permite identificar não somente o valor adicionado doméstico e estrangeiro contido nas exportações como também possibilita avaliar o grau de integração produtiva dos países, na medida em que mapeia as interações, via comércio, das estruturas produtivas nacionais. Nas próximas seções, utilizaremos os resultados da referida decomposição para avaliar as diferenças setoriais e geográficas da especialização exportadora brasileira, com o intuito de identificar os três aspectos acima mencionados - qual seja, qual a parcela das exportações que corresponde ao valor adicionado doméstico, o que é agregado via importações de sócios e ainda examinar o quão imbricado está a estrutura produtiva brasileira com seus principais parceiros comerciais. A primeira seção avalia a composição das exportações brutas totais brasileiras, comparando-a com outros países. Em seguida, avalia-se as exportações brutas brasileiras desagregadas em 5 grandes setores.

\footnotetext{
${ }^{8}$ Sobre a metodologia da WIOT, ver Dietzenbacher et al. (2013).
} 


\subsection{Inserção brasileira nas cadeias globais de valor a partir de uma perspectiva comparada}

Antes de realizarmos a análise nos níveis setorial e bilateral das exportações brutas brasileiras, comparamos o resultado da decomposição de WWZ $(2014,2018)$ para as exportações totais do Brasil com aquelas de economias selecionadas. Os dois primeiros termos do valor adicionado doméstico (DVA_FIN e o DVA_INT) correspondem ao valor adicionado doméstico contido nas exportações de bens finais e bens intermediários que serão consumidos no país importador direto. Esses termos são destinados à demanda final dos países e, portanto, não configuram exportações que se integram às cadeias de valor. Desse modo, serão analisados apenas os demais termos (DVA_INTrex1 até o MDC) cujas parcelas representam participação nas CGV, entendendo-se por integração às CGV as exportações que atravessam mais de uma fronteira (são reexportadas por outros países ou exportações domésticas que contém valor adicionado estrangeiro). ${ }^{9}$

A soma da participação dos três elementos que compõem o valor adicionado doméstico associado às cadeias - DVA_INTrex1, DVA_INTrex2 e DVA_INTrex3 - atingiram 20\% das exportações brutas brasileiras, com o primeiro termo como o mais importante no caso do Brasil (10\% em 2014). Como este último corresponde ao valor adicionado doméstico exportado via bens intermediários para os importadores diretos, que o reexportam como bens intermediários para terceiros países, isso mostra o quanto o Brasil está no início das CGV. A Rússia mostra características semelhantes e mesmo mais acentuadas do que o Brasil devido a importância de suas exportações de petróleo e gás: é o país que apresenta o maior valor a partir da soma dos três termos. Em termos de evolução, apenas Japão, Coreia do Sul e Índia mostraram redução da soma do valor adicionado doméstico associado às CGV ao longo do período 2000-2014.

Os termos de valor adicionado doméstico que retornam ao país de origem se dividem na forma que retornam: em bens intermediários (RDV_INT), bens finais vindos do importador direto (RDV_FIN) e bens finais vindos de países terceiros (RDV_FIN2). No primeiro termo (RDV_INT), apenas EUA se destaca. Este aspecto está provavelmente associado ao tipo de integração produtiva com a indústria mexicana, onde as cadeias se iniciam nos EUA (com fornecimento de insumos) voltadas para o próprio mercado norte-americano. ${ }^{10}$ No caso brasileiro, a parcela de valor adicionado doméstico que retorna é ínfima, figurando junto com a Coreia do Sul com os menores percentuais.

Para WWZ $(2014,2018)$ a soma dos termos até aqui analisados é igual ao total da participação para frente nas CGV (forward linkages), que é chamado na literatura de VS1. Ou seja, esses termos da decomposição indicam todo o valor adicionado doméstico que é reexportado pelo mundo por meio de suas exportações. Para este indicador, o Brasil aparece em terceiro lugar, após Rússia e EUA.

Os termos referentes ao valor estrangeiro contido nas exportações domésticas - ou backward linkages - encontram-se embutidos em bens finais ou intermediários do importador direto ou de terceiros países. O Brasil apresenta uma participação bastante reduzida devido ao peso dos bens intensivos em recursos naturais. Embora tenha subido de 9,1\% em 2000 para 9,7\% das exportações brutas em 2014, ainda é pequeno relativamente a outros países, como EUA e Rússia, por exemplo. No outro extremo, com percentuais acima de 20\%, encontram-se México (29,7\%), Coreia do Sul (25,9\%) e UE (22,2\%). É importante ressaltar que, exceto para China, o percentual de valor adicionado estrangeiro aumentou para a maioria dos países, tendo Japão e Índia apresentado as maiores variações positivas.

\footnotetext{
${ }^{9}$ Wang et al. (2017) avançam ainda mais na análise das cadeias ao distinguir as exportações de um país segundo seu destino - mercado interno, exportações tradicionais (aquelas que são consumidas no país importador) e exportações associadas a CGV simples e complexas. Enquanto as exportações associadas as CGV simples atravessam duas fronteiras (são reexportadas sob a forma de produtos intermediários), as complexas atravessam um maior número de fronteiras. A utilidade dessa distinção reside na possibilidade de afinar a avaliação do grau de integração e a localização dos países nas cadeias.

${ }^{10}$ Resultados similares para o VS1*, valor adicionado que retorna ao país de origem, são encontrados por Hermida e Xavier (2018) a partir da metodologia de Koopman et al $(2010,2014)$ aplicada aos dados da versão antiga da base WIOD (1995 2011).
} 
Em relação às participações dos termos de valor adicionado estrangeiro proveniente de terceiros países nas exportações brutas do país (soma de OVA_FIN e OVA_INT), apenas o México apresenta um percentual elevado. Já o valor adicionado estrangeiro proveniente do importador direto contido nas exportações de bens finais e intermediários (MVA_FIN e MVA_INT, respectivamente) costuma superar aquele que provém de terceiros países, com exceção para o México, devido às importações provenientes dos EUA.

A distinção entre o valor estrangeiro contido nos bens finais e nos bens intermediários evidencia diferenças entre três países/regiões - China, México e UE - e os demais. Para China e México, que são zonas de processamento de exportações, e para a região europeia cuja produção é altamente integrada, a parcela do valor adicionado estrangeiro exportados através de bens finais (Soma de OVA_FIN e MVA_FIN) é superior à parcela contida nos bens intermediários (OVA_INT e MCA_INT).

Entre os termos que refletem a pura dupla contagem, a doméstica ${ }^{11}$ é baixa para todos os países (menos de $1 \%$ das exportações brutas, sendo $0 \%$ para o Brasil). O peso da pura dupla contagem do valor adicionado estrangeiro é maior, superando 6\%, em três casos: UE, Coreia do Sul e Japão. Brasil e Rússia apresentam níveis muito baixos e similares de dupla contagem.

A decomposição detalhada confirma a baixa integração do Brasil nas chamadas CGV e sugere que sua especialização em recursos naturais é um dos fatores explicativos, dada as similaridades em diversos aspectos com a Rússia. Esta desagregação avança relativamente àquelas mais agregadas por permitir a diferenciação do caso brasileiro relativamente a outros países como EUA e Japão: para todos esses países o valor adicionado doméstico é bastante elevado, porém, para Rússia e Brasil esse é exportado majoritariamente sob a forma de commodities agrícolas e/ou industriais, de modo que essa é a sua principal forma de inserção nas CGV.

\subsection{Análise setorial das exportações brasileiras totais em 2000 e 2014}

A fim de facilitar a leitura, as análises desagregadas setorialmente mostram os resultados em termos de 5 grandes setores. Como pode-se ver pela Tabela 2, a Industria de Transformação é o setor que exporta maior parcela de valor adicionado no Brasil, apesar da queda de participação entre $2000 \mathrm{e}$ 2014. Os principais setores manufatureiros em 2014 são: Produtos Alimentícios, Bebidas e Produtos do Tabaco (16,6\% de participação nas exportações brutas brasileiras); Metais Básicos (7,2\%); Veículos Motorizados, Trailers e Semi-Trailers (4,7\%); Químicos e Produtos Químicos (4,4\%); Máquinas e Equipamentos (3,1\%); Coque e Produtos de Petróleo Refinado (3\%) e Papel e Produtos de Papel (2,7\%). A maior parcela do valor adicionado doméstico exportado por esses setores é destinada à demanda final do importador direto (soma de DVA_FIN e DVA_INT), indicando que o valor adicionado doméstico atravessa poucas fronteiras, sofrendo, dessa forma, poucas transformações industriais.

$\mathrm{Na}$ análise das exportações manufatureiras que se integram às CGV percebe-se uma mudança no padrão de participação para frente (foward participation) observado em 2000. Em 2014, os componentes para frente (VS1) e para trás (VS) mostram percentuais similares em virtude sobretudo da redução do valor adicionado doméstico contido nas exportações de outros países.

Em geral, a participação da Industria de Transformação brasileira nas CGV ocorre por meio de exportações e importações de bens intermediários (ver componentes DVA_INTre1 para o valor adicionado doméstico e FVA_INT para o valor adicionado estrangeiro). O setor de Mineração foi o que apresentou maior crescimento em termos de integração às CGV. Isso se deve principalmente ao incremento de sua participação para frente, diante de um crescimento menor da participação para trás. O crescimento do VS1 foi devido, principalmente, ao aumento de participação nas exportações brutas

\footnotetext{
${ }^{11}$ DDC_FIN, que significa a pura dupla contagem do valor adicionado doméstico contido nas (re)exportações de bens finais pelo país. DDC_INT, que significa a pura dupla contagem do valor adicionado doméstico contido nas (re)exportações de bens intermediários pelo país.
} 
do termo que representa o VA brasileiro reexportado como bem intermediário utilizado pelo país terceiro para uso final (consumo e produção) entre 2000 e 2014.

Para a Agricultura, a participação nas CGV também cresceu entre 2000 e 2014, principalmente o VS1 (1,3 pontos percentuais de crescimento). No entanto, diferentemente da Mineração, o crescimento da participação para frente ocorreu devido ao aumento da parcela de participação nas exportações brutas brasileiras do valor adicionado doméstico reexportado para países terceiros como bens finais. Isso significa que maior parte do VA reexportado atravessa apenas uma fronteira como bem intermediário. O principal setor dessa indústria foi o de Produção e Corte de Animais (14,1\% das exportações brasileiras e crescimento de sete pontos percentuais) e, conforme esperado, sua participação nas CGV é para frente nos dois períodos. Em 2014, dos 4,4\% de participação das exportações desse setor nas CGV, $2,5 \%$ representavam participação para frente.

Para os serviços, a participação nas exportações brasileiras caiu, apesar das exportações que se integram às CGV manterem sua parcela nas exportações brutas. Para Outros Serviços, o mesmo padrão se aplica. Dentre todos os setores, Serviços e Outros serviços são aqueles com menor (e decrescente) participação nas exportações do Brasil. Esse é um resultado esperado na medida em que as exportações de serviços constituem uma pequena parcela dentro das exportações totais brasileiras. 
Tabela 1. Decomposição das exportações brutas totais do Brasil e de países selecionados - 2000 e 2014 (em \% das exportações brutas)

\begin{tabular}{|c|c|c|c|c|c|c|c|c|c|c|c|c|c|}
\hline País & Ano & DVA_FIN & DVA_INT & DVA_INTrex1 & DVA_INTrex2 & DVA_INTrex3 & RDV1 & DDC2 & FVA_FIN3 & FVA_INT4 & FDC5 & VS1 & VS \\
\hline \multirow{2}{*}{ Brasil } & 2000 & 32.5 & 38.7 & 7.7 & 7.6 & 1.9 & 0.3 & 0 & 4.6 & 4.6 & 2.2 & 17.5 & 9.2 \\
\hline & 2014 & 22.2 & 44.4 & 10.3 & 7.3 & 2.4 & 0.4 & 0 & 3.6 & 5.7 & 3.1 & 20.4 & 9.3 \\
\hline \multirow{2}{*}{ China } & 2000 & 46.5 & 23.9 & 5.3 & 5.5 & 1.4 & 0.9 & 0.3 & 9.7 & 4.7 & 2.7 & 13.1 & 14.4 \\
\hline & 2014 & 42.1 & 26.5 & 5.8 & 4.9 & 1.5 & 2.4 & 0.9 & 7.9 & 5.2 & 3.2 & 14.6 & 13.1 \\
\hline \multirow{2}{*}{ México } & 2000 & 36.9 & 23.6 & 3.2 & 2.6 & 0.8 & 0.4 & 0.2 & 21.9 & 15.7 & 2.5 & 7 & 37.6 \\
\hline & 2014 & 29.2 & 27.7 & 4.7 & 3.2 & 1.1 & 0.5 & 0.2 & 18.9 & 13.3 & 3.6 & 9.5 & 32.2 \\
\hline \multirow{2}{*}{ EUA } & 2000 & 34.6 & 30.8 & 6.2 & 5.8 & 1.5 & 10.4 & 0.8 & 3.7 & 3.3 & 2.9 & 23.9 & 7 \\
\hline & 2014 & 30.4 & 33.6 & 8.6 & 6.2 & 2 & 6.4 & 0.7 & 4.2 & 4.6 & 3.3 & 23.2 & 8.8 \\
\hline \multirow{2}{*}{ União Europeia } & 2000 & 32.9 & 26.3 & 6.9 & 6.8 & 1.8 & 1.2 & 0.4 & 10.5 & 7.9 & 5.6 & 16.7 & 18.4 \\
\hline & 2014 & 26.6 & 23.9 & 8.2 & 6.3 & 2.2 & 1 & 0.5 & 11.9 & 10.4 & 9 & 17.7 & 22.3 \\
\hline \multirow{2}{*}{ Japão } & 2000 & 41.7 & 29.3 & 7.4 & 7.8 & 2.3 & 1.9 & 0.4 & 4 & 3.2 & 2.3 & 19.4 & 7.2 \\
\hline & 2014 & 32.1 & 27.8 & 7.5 & 5.9 & 2.1 & 1 & 0.3 & 7.8 & 9.1 & 6.1 & 16.5 & 16.9 \\
\hline \multirow{2}{*}{ Coreia do Sul } & 2000 & 30.6 & 24.1 & 5.7 & 7.6 & 1.9 & 0.3 & 0.2 & 11.5 & 10.9 & 7.3 & 15.5 & 22.4 \\
\hline & 2014 & 25.5 & 24.6 & 6.5 & 6.1 & 1.8 & 0.3 & 0.3 & 12.1 & 13.5 & 8.8 & 14.7 & 25.6 \\
\hline \multirow{2}{*}{ Rússia } & 2000 & 10.3 & 51.2 & 16.2 & 9.5 & 3.6 & 0.3 & 0.1 & 1.2 & 4.1 & 2.9 & 29.6 & 5.3 \\
\hline & 2014 & 7.9 & 50.6 & 19.9 & 8.4 & 4.8 & 0.8 & 0.1 & 1 & 3.4 & 2.7 & 33.9 & 4.4 \\
\hline \multirow{2}{*}{ Índia } & 2000 & 39 & 32.7 & 6.9 & 6.7 & 1.7 & 0.3 & 0 & 4.8 & 4.9 & 2.7 & 15.6 & 9.7 \\
\hline & 2014 & 35.4 & 29.7 & 7 & 5 & 1.8 & 0.4 & 0.1 & 6.7 & 8.3 & 4.9 & 14.2 & 15 \\
\hline
\end{tabular}

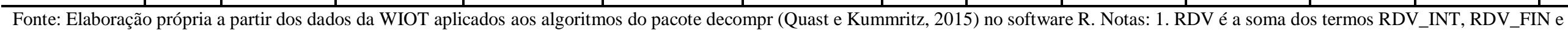

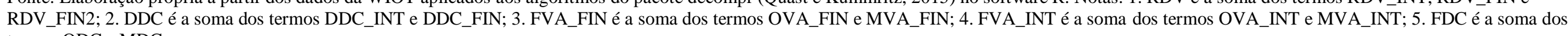
termos ODC e MDC. 
Tabela 2. Decomposição das exportações brutas do Brasil para grandes grupos industriais - 2000 e 2014 (em \% das exportações brutas)

\begin{tabular}{|c|c|c|c|c|c|c|c|c|c|c|c|c|c|}
\hline Indústria & Ano & DVA_FIN & DVA_INT & DVA_INTrex1 & DVA_INTrex2 & DVA_INTrex3 & $\mathrm{RDV}^{1}$ & $\mathrm{DDC}^{2}$ & FVA_FIN ${ }^{3}$ & FVA_INT $^{4}$ & $\mathrm{FDC}^{5}$ & VS1 & VS \\
\hline \multirow{2}{*}{ Agricultura } & 2000 & 0.9 & 4.6 & 0.4 & 1.1 & 0.1 & 0.0 & 0.0 & 0.1 & 0.4 & 0.1 & 1.6 & 0.5 \\
\hline & 2014 & 0.6 & 9.3 & 0.9 & 1.8 & 0.2 & 0.1 & 0.0 & 0.1 & 1.1 & 0.4 & 2.9 & 1.5 \\
\hline \multirow{2}{*}{ Mineração } & 2000 & 0.2 & 3.0 & 1.1 & 0.4 & 0.2 & 0.1 & 0.0 & 0.0 & 0.2 & 0.1 & 1.8 & 0.4 \\
\hline & 2014 & 0.1 & 9.8 & 3.7 & 1.2 & 0.7 & 0.2 & 0.0 & 0.0 & 0.9 & 0.6 & 5.9 & 1.5 \\
\hline \multirow{2}{*}{ Manufaturas } & 2000 & 26.8 & 23.9 & 4.8 & 5.0 & 1.4 & 0.2 & 0.0 & 4.2 & 3.5 & 1.8 & 11.3 & 9.5 \\
\hline & 2014 & 17.9 & 18.3 & 4.4 & 3.4 & 1.2 & 0.2 & 0.0 & 3.3 & 3.7 & 2.0 & 9.1 & 9.0 \\
\hline \multirow{2}{*}{ Serviços } & 2000 & 2.3 & 4.6 & 0.9 & 0.7 & 0.2 & 0.0 & 0.0 & 0.1 & 0.2 & 0.1 & 1.8 & 0.4 \\
\hline & 2014 & 1.7 & 4.2 & 0.9 & 0.5 & 0.2 & 0.0 & 0.0 & 0.1 & 0.2 & 0.1 & 1.7 & 0.4 \\
\hline \multirow{2}{*}{$\begin{array}{c}\text { Outros } \\
\text { Serviços }\end{array}$} & 2000 & 2.3 & 2.7 & 0.4 & 0.3 & 0.1 & 0.0 & 0.0 & 0.2 & 0.2 & 0.1 & 0.9 & 0.4 \\
\hline & 2014 & 1.9 & 2.9 & 0.5 & 0.3 & 0.1 & 0.0 & 0.0 & 0.1 & 0.2 & 0.1 & 0.9 & 0.4 \\
\hline
\end{tabular}

Fonte: Elaboração própria a partir dos dados da WIOT aplicados aos algoritmos do pacote decompr (Quast e Kummritz, 2015) no software R. Notas: 1. RDV = RDV_INT + RDV_FIN + RDV_FIN2; 2. DDC = DDC_INT + DDC_FIN; 3. FVA_FIN = OVA_FIN + MVA_FIN; 4. FVA_INT = OVA_INT + MVA_INT; 5. FDC = ODC + MDC. 6. A soma das parcelas de todos os componentes para todos os setores corresponde a 100\% para cada ano. 


\section{Especialização geográfica e setorial brasileira: perfil das exportações em valor adicionado para seus principais parceiros comerciais (China, UE e EUA)}

Nesta seção, será analisada a decomposição das exportações brutas brasileiras para três de seus principais parceiros comerciais - China, EUA e UE. Juntos, em 2014, estes países/regiões absorveram 42,5\% das exportações brutas brasileiras. Infelizmente, os países da América Latina e do Caribe, que absorveram cerca de $20 \%$ das exportações brasileiros, encontram-se sub-representados na base de dados WIOD $^{12}$. A consideração destes países seria desejável não somente por conta de seu peso nas exportações, como também pela composição delas. As exportações de manufaturados são particularmente importantes para os vizinhos latino-americanos, apresentam um perfil de maior sofisticação do que as exportações para os demais parceiros e ainda refletem algum grau de articulação produtiva, ponto relevante do ponto de vista da análise das CGV e do desenvolvimento produtivo. ${ }^{13}$

O gráfico 1 mostra a evolução da parcela das exportações brutas brasileiras para cada um dos parceiros e evidencia uma mudança importante na distribuição geográfica das exportações brasileiras. Parceiros tradicionais como os EUA e a UE perderam importância em detrimento da China, que se tornou ao longo dos anos 2000 o principal destino das exportações brasileiras.



Fonte: Elaboração própria a partir da base de dados da WIOD aplicada ao pacote de algoritmos decompr no Software R.

O gráfico 2 apresenta a parcela do valor adicionado brasileiro exportado e não retorna ao Brasil (retira-se a dupla contagem). Aqui, estão incluídas as exportações brasileiras que são consumidas no país importador, mas também aquelas que são reexportadas (estas últimas são aquelas consideradas como refletindo uma maior participação nas CGV). A participação destes três países no valor

\footnotetext{
12 Para Cadestin, Gourdon e Kowalski (2016), a dimensão regional da atividade da cadeia de valor é aparente quando se examina a participação do GVC para trás e para a frente pela origem e destino do valor adicionado comercializado. Na América Latina, apenas 9\% do valor estrangeiro adicionado utilizado para as exportações, em média, foi obtido na região ou exportado como intermediário para processamento adicional na região. Na União Europeia e no Sudeste Asiático - as duas regiões com algumas das maiores taxas globais de participação nas CGV - as ligações regionais foram muito mais fortes. Por exemplo, na União Europeia, uma média de $49 \%$ do valor adicionado estrangeiro usado para as exportações veio de outros países da UE e no Sudeste Asiático, este índice foi de 40\% em 2011. Ver também Zaclicever (2017).

${ }^{13}$ Para maiores detalhes, ver Castilho, Costa e Torracca (2019) e Castilho (2012).
} 
adicionado doméstico contido nas exportações brasileiras ${ }^{14}$ mantém a ordenação do valor bruto (Gráfico 1): a UE respondendo por 16,4\%, a China por 15,6\% e os EUA, 10,3\%.

A parcela do valor adicionado doméstico nas exportações brutas para cada um dos parceiros é bastante elevada, sendo mais alta no caso da China (89\%), equivalente ao total brasileiro no caso da UE (87\%) e, enfim, mais baixa no caso dos EUA (82\%). Estes percentuais estão fortemente associados à especialização das exportações para cada um desses parceiros. Em 2000, houve um forte crescimento das exportações brutas e do valor adicionado doméstico para a China, ainda que a taxa de crescimento das exportações brutas tenha superado a variação do valor adicionado doméstico contido nas exportações brasileiras para o mercado chinês. Para EUA e UE, a queda das exportações brutas foi acompanhada de uma queda pouco maior do valor adicionado doméstico das exportações. Por consequência, a maior redução da parcela do valor adicionado doméstico nas exportações brutas ocorreu no caso chinês.

Gráfico 2 - Evolução da parcela de China, Estados Unidos e União Europeia no valor adicionado doméstico contido nas exportações brasileiras, para 2000, 2005, 2011 e 2014 (\% das exportações brutas)

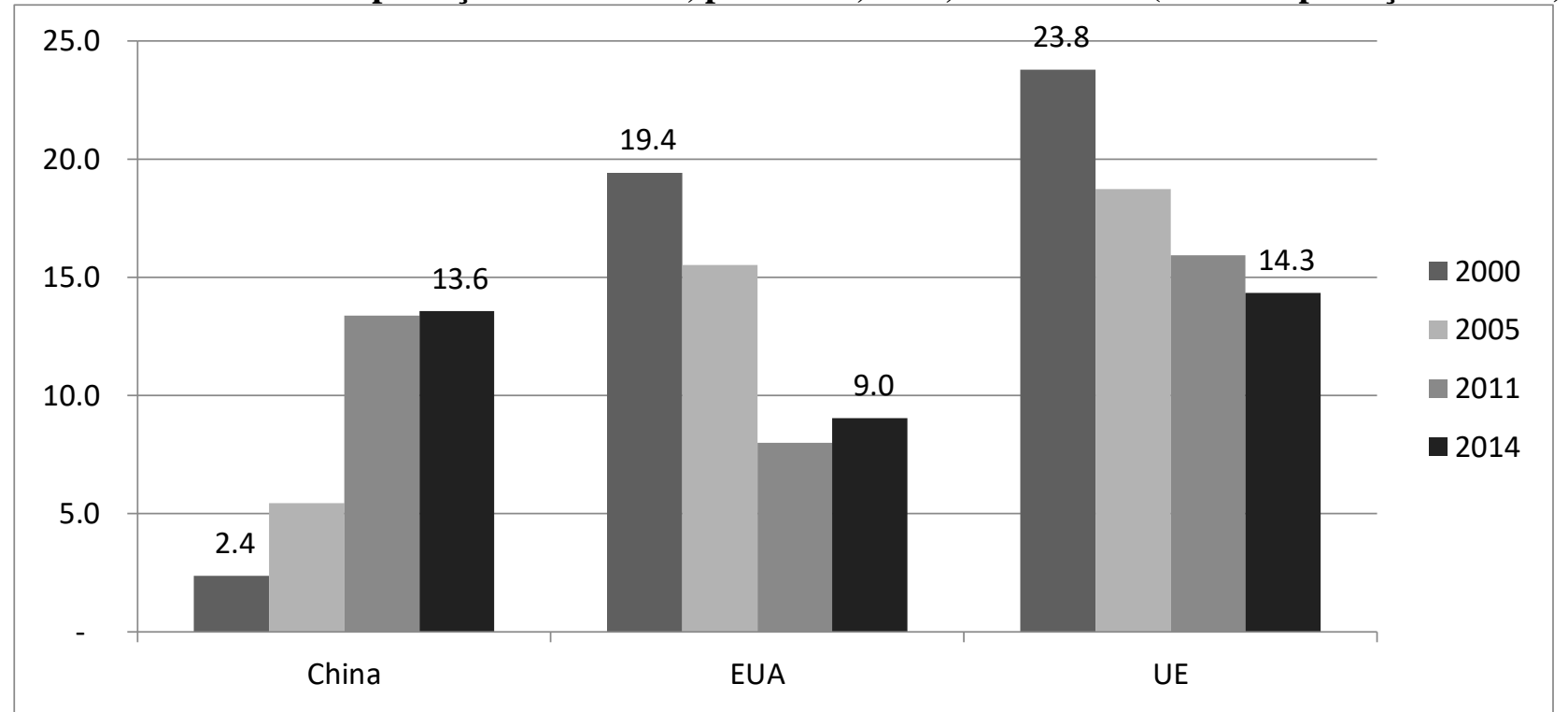

Fonte: Elaboração própria a partir da base de dados da WIOD aplicada ao pacote de algoritmos decompr no Software R.

A comparação entre os componentes da decomposição para os três principais parceiros do Brasil confirma as tendências inversas de China, por um lado, e de UE e EUA, por outro lado. Todos os termos que apresentaram variação diferente de zero, cresceram no caso chinês e se reduziram nos demais casos. Para esses três países/regiões, o valor adicionado doméstico incorporado nas exportações consumidas diretamente pelo importador responde pela maior parte das exportações brutas (para os três países, a soma dos elementos DVA_FIN e DVA_INT correspondem a cerca de $72 \%$ das exportações brutas bilaterais). Para os três igualmente, o valor adicionado doméstico está majoritariamente incorporado nas exportações de bens intermediários utilizados para esses países produzirem e consumirem seus bens finais (DVA_INT), sendo essa característica mais acentuada no caso chinês.

\footnotetext{
${ }^{14}$ Esses percentuais são calculados a partir da razão entre os dados apresentados no Gráfico e o percentual de valor adicionado doméstico contido nas exportações totais, que, de acordo com a Tabela 1, era de 88,7\% das exportações brutas em 2000 e de $87 \%$ em 2014.
} 
As exportações de valor adicionado doméstico que denotam integração às CGV são representadas pelos termos DVA_INTrex1 até o FDC, correspondendo tanto ao valor adicionado doméstico reexportado pelos parceiros comerciais, quanto valor adicionado estrangeiro exportado pelo Brasil para esses mesmos parceiros. A participação das exportações associadas as CGV nas exportações brutas bilaterais aumentaram nos três países de 2000 a 2014, atingindo um percentual similar (para cada um dos destinos, a razão entre exportações associadas as CGV e exportações totais bilaterais encontra-se em torno de $28 \%$ ).

A análise dos indicadores de participação para frente (VS1) e para trás (VS) revelam um padrão diferenciado das exportações brasileiras para os três países/regiões. De um lado, com a China, a participação para frente predomina, visto que em 2014, o VS1 apresentava um valor $(2,6 \%)$ superior ao de VS (1,6\%), além de superar também o percentual de VS1 dos demais parceiros. Esta participação e fortemente impulsionada pelo valor adicionado brasileiro reexportado pela China como produtos para consumo em países terceiros (DVA_INTrex2) - o que, na nomenclatura de Wang et al. (2017), seria participação em "CGV simples".

Tabela 3. Evolução dos componentes da decomposição de Wang, Wei e Zhu $(2014,2018)$ para a China, EUA e UE (\% das exportações brutas totais)

\begin{tabular}{|c|c|c|c|c|c|c|c|c|c|c|c|c|}
\hline País & Ano & $\begin{array}{c}\text { DVA_ }_{-} \\
\text {FIN }\end{array}$ & $\begin{array}{c}\text { DVA_ }_{-} \\
\text {INT }\end{array}$ & \begin{tabular}{c|} 
DVA_ \\
INTrex1
\end{tabular} & \begin{tabular}{|c|} 
DVA_ \\
INTrex2
\end{tabular} & \begin{tabular}{c|} 
DVA_ \\
INTrex3
\end{tabular} & $\mathrm{RDV}^{1}$ & $\mathrm{DDC}^{2}$ & $\mathrm{FVA}^{3}$ & $\mathrm{FDC}^{4}$ & $\mathrm{VS}^{5}{ }^{5}$ & $\mathrm{VS}^{6}$ \\
\hline \multirow{3}{*}{ China } & 2000 & 0.6 & 1.4 & 0.1 & 0.2 & 0.0 & 0.0 & 0.0 & 0.1 & 0.0 & 0.3 & 0.2 \\
\hline & 2014 & 1.3 & 9.7 & 1.0 & 1.4 & 0.2 & 0.1 & 0.0 & 1.2 & 0.3 & 2.6 & 1.6 \\
\hline & $\begin{array}{c}\text { Variação } 2000- \\
14 \text { (p.p.) }\end{array}$ & 0.7 & 8.2 & 0.8 & 1.2 & 0.2 & 0.1 & 0.0 & 1.1 & 0.3 & 2.3 & 1.4 \\
\hline \multirow{3}{*}{ EUA } & 2000 & 8.3 & 9.5 & 0.7 & 0.7 & 0.3 & 0.0 & 0.0 & 2.9 & 0.3 & 1.6 & 3.1 \\
\hline & 2014 & 2.2 & 5.6 & 0.6 & 0.4 & 0.2 & 0.0 & 0.0 & 1.6 & 0.3 & 1.3 & 1.9 \\
\hline & $\begin{array}{c}\text { Variação 2000- } \\
14 \text { (p.p.) }\end{array}$ & -6.1 & -3.9 & -0.1 & -0.2 & -0.1 & 0.0 & 0.0 & -1.3 & 0.0 & -0.4 & -1.3 \\
\hline \multirow{3}{*}{$\begin{array}{c}\text { União } \\
\text { Europeia }\end{array}$} & 2000 & 8.3 & 9.5 & 0.7 & 0.7 & 0.3 & 0.0 & 0.0 & 1.8 & 0.7 & 1.7 & 2.5 \\
\hline & 2014 & 3.4 & 5.6 & 0.6 & 0.4 & 0.2 & 0.1 & 0.0 & 1.2 & 0.9 & 1.3 & 2.0 \\
\hline & $\begin{array}{c}\text { Variação 2000- } \\
14 \text { (p.p.) }\end{array}$ & -4.7 & -3.9 & -0.1 & -0.2 & -0.1 & 0.0 & 0.0 & -0.6 & 0.1 & -0.4 & -0.5 \\
\hline
\end{tabular}

Fonte: Elaboração própria a partir dos dados da WIOT aplicados aos algoritmos do pacote decompr (Quast e Kummritz, 2015) no software R. Notas: 1. RDV $=$ RDV_INT + RDV_FIN + RDV_FIN2; 2 . DDC $=$ DDC_INT + DDC_FIN; 3. FVA = OVA_FIN + MVA_FIN +OVA_INT + MVA_INT; 4. FDC $=$ ODC + MDC.

5. VS1, para Wang, Wei e Zhu $(2014,2018)$, é a soma de DVA_INTrex $(1,2$ e 3) com RDV e VS é a soma resultante de DDC, FVA e FDC

Para EUA e UE, a participação para trás (VS) supera a para frente (VS1). Ambos indicadores têm valores parecidos em 2014 para os dois parceiros, porém, resultam de evolução diferenciada e tem uma composição também distinta. No caso da evolução, o decréscimo do VS no caso norte-americano foi bastante acentuado, indicando que a participação como fornecedor de insumos para que os EUA produzam suas exportações e como demandante de valor adicionado estrangeiro para produzir as exportações para os EUA está mais equilibrada. Para a Europa, a redução dos dois tipos de participação foi equivalente. Em termos de composição do VS1, a principal redução veio do componente relacionado as exportações de valor adicionado estrangeiro de países terceiros, atingindo 1,2\% em 2014. No caso da UE, além desse componente, aquele referente a dupla contagem de valor adicionado doméstico contido nas reexportações de bens pelos países europeus se destaca relativamente aos dois outros parceiros ( $0,9 \%$ do total das exportações brutas brasileiras). $\mathrm{O}$ fato de haver dupla contagem de valor adicionado estrangeiro nas reexportações do Brasil para a UE - superior as da China e dos EUA ( $0,3 \%$ nestes dois casos face aos $0,9 \%$ no caso europeu) - sugere a existência de maior proximidade ou integração do Brasil em cadeias nas quais a UE participa. 


\subsection{Composição setorial das exportações brasileiras em valor adicionado para China, EUA e UE}

As características da especialização das exportações brasileiras em valor adicionado analisadas acima em muito refletem a estrutura setorial das exportações bilaterais. A tabela 4 compara a decomposição para os 5 grandes setores das exportações dos parceiros comerciais selecionados.

Para a China, o setor agrícola é aquele que tem maior valor adicionado doméstico incorporado nas exportações (4,6\% das exportações brutas totais brasileiras), o que é válido tanto na comparação com a exportação dos demais setores para o próprio mercado chinês, quanto na comparação com as exportações agrícolas para os dois outros parceiros. A mineração ocupa segundo lugar (também nos dois tipos de comparação). A maior parte do valor adicionado doméstico destes dois setores é exportado como bens intermediários para uso final na própria China. Ainda que a participação para frente (VS1) seja pequena, estes setores ainda se destacam por serem os mais integrados nas CGV. A participação para trás (VS), inferior a participação para frente (VS1), é maior na agricultura, mas nesse quesito a Industria de Transformação apresenta indicador semelhante à da Mineração. Na Indústria de Transformação três setores se destacam: Alimentos, Bebidas e Tabaco, cujas exportações são voltadas integralmente para uso doméstico chinês, Papel e seus produtos e Metais básicos. Estes dois últimos apresentam uma participação nas CGV relativamente importante, para trás e para frente. Dentre os setores de serviços, as exportações de Atividades de Contabilidade, Jurídicas e Consultoria Administrativa são as únicas a apresentarem índices que difiram significativamente de zero, sendo o mercado chinês o principal destino das exportações de valor adicionado doméstico.

Os EUA apresentam uma especialização diferente: a Industria de Transformação representa o setor com maior importância em termos de valor adicionado doméstico, sobretudo aquele contido nas exportações voltadas para o próprio mercado norte-americano. Vale assinalar a queda do valor adicionado doméstico associado as exportações de bens manufaturados, cuja participação passou de 17,4\% das exportações brutas totais em 2000 para 6,7\% em 2014. Esse setor apresenta índices de participação nas cadeias bem superiores aos demais, sendo que a participação para trás $(1,6 \%)$ é superior a participação para frente $(1 \%)$. As exportações de manufaturados, além de superiores àquelas para a China, são bem mais diversificadas. Metais, Químicos, Papel e Produtos de Coque e Petróleo são os principais setores em termos de importância do valor adicionado doméstico. Estes setores são aqueles com maior participação nas CGV. Em geral o valor adicionado estrangeiro presente nas exportações (VS) é superior ao valor adicionado doméstico contido nas exportações associadas as CGV (VS1).

O perfil da UE é o mais diversificado. A Indústria de transformação é aquela com maior peso em termos de geração de valor adicionado doméstico, porém a agricultura também responde por parcela relevante das exportações brutas totais. Por fim, a participação dos serviços supera àquela observada para os outros dois parceiros. Outro aspecto relevante das exportações de manufaturas da UE consiste no fato de que a participação do valor adicionado doméstico nas exportações associadas a CGV (VS1) supera aquela observada para todos os setores dos demais países, atestando uma maior integração das exportações brasileiras nas CGV das quais a UE participa. Vale assinalar que no caso das exportações manufatureiras europeias, o valor adicionado estrangeiro é inferior ao norteamericano. Dos setores manufatureiros, Alimentos e Bebidas é o mais importante, porém, ele guarda a característica de exportar bens não somente para consumo na própria UE, mas também para serem processados e reexportados por ela. Outros setores com participação importante são metais básicos e produtos químicos, cujo valor adicionado doméstico decorrente das exportações associadas as CGV supera aquele gerado nas exportações para uso final no mercado europeu. No caso da agricultura, a participação para frente é relativamente elevada, e no caso dos serviços, as exportações dirigem-se basicamente para a própria UE, apresentando um indicador VS1 bastante baixo. 
Tabela 4. Evolução dos componentes da decomposição de Wang, Wei e Zhu $(2014,2018)$ para a China, EUA e UE por grandes setores (\% das exportações brutas totais)

\begin{tabular}{|c|c|c|c|c|c|c|c|c|c|c|c|c|}
\hline Pais & Setor & $\begin{array}{c}\text { DVA_ } \\
\text { FIN }\end{array}$ & $\begin{array}{c}\text { DVA_- }_{-} \\
\text {INT }\end{array}$ & $\begin{array}{c}\text { DVA_- }_{-} \\
\text {INTrex1 }\end{array}$ & $\begin{array}{c}\text { DVA_ } \\
\text { INTrex2 }\end{array}$ & $\begin{array}{c}\text { DVA_ } \\
\text { INTrex3 }\end{array}$ & $\mathrm{RDV}^{1}$ & $\mathrm{DDC}^{2}$ & $\mathrm{FVA}^{3}$ & FDC $^{4}$ & $\mathrm{VSS}^{5}$ & $\mathrm{VS}^{6}$ \\
\hline \multirow{5}{*}{ China } & Agricultura & 0.0 & 4.6 & 0.3 & 0.6 & 0.1 & 0.0 & 0.0 & 0.6 & 0.1 & 1.0 & 0.7 \\
\hline & Mineração & 0.0 & 2.8 & 0.4 & 0.4 & 0.1 & 0.0 & 0.0 & 0.3 & 0.1 & 0.9 & 0.4 \\
\hline & Manufatura & 0.5 & 1.5 & 0.2 & 0.3 & 0.0 & 0.0 & 0.0 & 0.3 & 0.1 & 0.5 & 0.4 \\
\hline & Outros serviços & 0.3 & 0.2 & 0.0 & 0.0 & 0.0 & 0.0 & 0.0 & 0.0 & 0.0 & 0.1 & 0.0 \\
\hline & Serviços & 0.4 & 0.6 & 0.1 & 0.1 & 0.0 & 0.0 & 0.0 & 0.0 & 0.0 & 0.2 & 0.0 \\
\hline \multirow{5}{*}{ EUA } & Agricultura & 0.1 & 0.5 & 0.0 & 0.0 & 0.0 & 0.0 & 0.0 & 0.1 & 0.0 & 0.1 & 0.1 \\
\hline & Mineração & 0.0 & 0.7 & 0.1 & 0.0 & 0.0 & 0.0 & 0.0 & 0.1 & 0.0 & 0.2 & 0.1 \\
\hline & Manufatura & 1.9 & 4.0 & 0.4 & 0.3 & 0.1 & 0.0 & 0.0 & 1.4 & 0.2 & 1.0 & 1.6 \\
\hline & Outros serviços & 0.1 & 0.2 & 0.0 & 0.0 & 0.0 & 0.0 & 0.0 & 0.0 & 0.0 & 0.0 & 0.1 \\
\hline & Serviços & 0.0 & 0.2 & 0.0 & 0.0 & 0.0 & 0.0 & 0.0 & 0.0 & 0.0 & 0.0 & 0.0 \\
\hline \multirow{5}{*}{ UE } & Agricultura & 0.2 & 1.4 & 0.3 & 0.7 & 0.1 & 0.0 & 0.0 & 0.2 & 0.1 & 1.1 & 0.3 \\
\hline & Mineração & 0.0 & 0.5 & 0.3 & 0.1 & 0.1 & 0.0 & 0.0 & 0.0 & 0.0 & 0.5 & 0.1 \\
\hline & Manufatura & 2.5 & 2.4 & 1.3 & 1.2 & 0.4 & 0.0 & 0.0 & 0.8 & 0.6 & 2.9 & 1.4 \\
\hline & Outros serviços & 0.4 & 0.5 & 0.1 & 0.1 & 0.0 & 0.0 & 0.0 & 0.1 & 0.0 & 0.2 & 0.1 \\
\hline & Serviços & 0.3 & 0.9 & 0.3 & 0.2 & 0.1 & 0.0 & 0.0 & 0.1 & 0.0 & 0.7 & 0.1 \\
\hline
\end{tabular}

Fonte: Elaboração própria a partir dos dados da WIOT aplicados aos algoritmos do pacote decompr (Quast e Kummritz, 2015) no software R. Notas: 1. RDV= RDV_INT + RDV_FIN + RDV_FIN2; 2. DDC $=$ DDC_INT + DDC_FIN; 3. FVA = OVA_FIN + MVA_FIN +OVA_INT + MVA_INT; 4. FDC = ODC + MDC. 5. VS1, para Wang, Wei e Zhu (2014, 2018), é a soma de DVA_INTrex (1, 2 e 3) com RDV e VS é a soma resultante de DDC, FVA e FDC.

\section{Conclusões}

A difusão das redes ou cadeias globais de produção e o aprofundamento da fragmentação da produção a partir da década de 1980 exigem novas ferramentas para avaliar as interações pelos lados da oferta e da demanda entre os países, que são avaliadas de forma inadequada pelas estatísticas tradicionais de comércio. As tabelas mundiais de insumo-produto têm sido instrumentais no preenchimento da lacuna das fontes estatísticas tradicionais por traçar de maneira mais acurada a contribuição ao comércio dos países em termos de valor adicionado. Metodologias alternativas foram desenvolvidas para utilizar esses dados de modo a medir o comércio em termos de valor adicionado, permitindo isolar a contribuição da demanda final e da demanda de bens intermediários para a produção nas diversas economias. Koopman et al (2014) propuseram um método rigoroso e abrangente para distinguir os fluxos agregados de exportação segundo a origem e o destino de seu conteúdo de valor adicionado. Aplicando essa estrutura a uma base de dados de matrizes de insumo-produto, como o WIOD, é possível explorar muitas questões relacionadas ao papel da fragmentação internacional da produção no comércio (Cappariello e Felettigh, 2015). No entanto, esta decomposição negligencia a dimensão bilateral e setorial dos fluxos comerciais e, consequentemente, pode ser inadequada para a análise de outras características como as ligações para trás e para a frente de um país dentro das cadeias globais de valor. Wang, Wei e Zhu $(2014,2018)$ avançaram metodologicamente ao propor uma ferramenta capaz de decompor o valor adicionado de forma desagregada bilateral e setorialmente.

Esse trabalho analisou a inserção internacional do Brasil, a partir desta última metodologia (Wang, Wei e Zhu, 2014, 2018). A contribuição do estudo consistiu em analisar tanto de forma agregada como desagregada setorial e por parceiro comercial, colocando, por um lado, as características da inserção brasileira em CGV em perspectiva com aquelas de outros países, e, por outro lado, permitindo a comparação da especialização e tipo de relação comercial do Brasil com três de seus principais parceiros.

A decomposição confirmou a baixa participação do Brasil nas CGV e mostrou que seu padrão de especialização comercial baseado em recursos naturais e o tamanho de seu mercado interno foram os dois principais fatores explicativos. Embora apresentando crescimento entre 2000 e 2014, a baixa participação brasileira nas CGV resulta de sua prévia especialização comercial em recursos naturais, 
aprofundada ao longo dos anos 2000 pela demanda - notadamente chinesa - por esses produtos e da expansão de seu mercado interno centrada no setor de serviços.

Os resultados evidenciaram que a maior parte das exportações dos países selecionados é voltada para atender a demanda final do país importador direto, enquanto uma menor parte se destinou à integração dos países nas CGV. Isso significa que o bem produzido em um país atravessa um menor número de vezes as fronteiras de outros países, indicando que uma importante parcela das exportações é do tipo "tradicional" ou se insere em "cadeias de valor simples", de acordo com Wang et al. (2017).

No entanto, a parcela de exportações diretas ou "tradicionais" - quando os produtos importados estão sendo consumidos ou processados para consumo no primeiro país para o qual as exportações são direcionadas - diminuiu globalmente em proveito das exportações para processamento adicional e exportação aumentaram, ilustrando a contínua expansão do comércio em GVC. A China, novamente, foi responsável por uma grande parte dessa mudança. Esta reorientação coincidiu com o declínio da importância dos destinos para processamento na União Europeia e nos parceiros regionais (Cadestin, Gourdon e Kowalski, 2016). Os países/regiões com maior participação nas CGV são Coreia, UE e México, que se destacam também com os maiores valores de participação para trás (VS).

A comparação dos indicadores de participação para frente nas CGV (forward linkages), chamado na literatura de VS1, com aquele referente a participação para trás (backward linkages), VS, revelou padrões bastante diferenciados entre os países. Se o Brasil mostrou um grau de participação próximo ao da China e da Índia, o perfil da inserção brasileira país se aproxima dos padrões apresentados pela Rússia e pelos EUA, com o componente VS1 superando significativamente o componente VS. No caso do Brasil e da Rússia, as exportações de bens intensivos em recursos naturais surgem como principal fator explicativo. Já no caso dos EUA, a contribuição para o valor doméstico presente nas exportações de outros países se explica por serviços e bens de maior sofisticação contidos em suas exportações.

Um elemento que se destaca, no caso europeu, é a pura dupla contagem de VA estrangeiro contido nas exportações para o bloco, sendo o elemento mais importante do valor adicionado estrangeiro embutido nas exportações brasileiras. Isto indica que no caso europeu, as exportações que para lá se dirigem tem um maior envolvimento nas CGV. Ainda assim, esse percentual e inferior ao total das exportações brasileiras e, mais ainda, relativamente aos demais países (com exceção da Rússia).

A análise da decomposição para exportações brasileiras totais por grandes setores mostra que a perda de dinamismo das exportações brasileiras de manufaturados em termos brutos é observada também em termos de valor adicionado doméstico das exportações. As exportações associadas às CGV não diminuem tanto quanto o valor adicionado doméstico nelas contidos devido a menor redução do valor adicionado estrangeiro contido nas exportações brasileiras. Os produtos manufaturados continuam a representar a maior parcela do valor adicionado doméstico das exportações, assim como das exportações associadas às CGV, porém, o ganho de importância da agricultura e da mineração relativamente a 2000 é expressivo. Os dois grupos de serviços mantiveram participações pequenas e, em geral, decrescentes nos indicadores referentes a participação nas $C G V$, indicando que este definitivamente não é um setor relevante para a inserção brasileira nas cadeias globais de valor.

A crescente importância da China como parceiro comercial brasileiro aparece tanto em termos de valor bruto das exportações quanto em termos de valor adicionado doméstico nas exportações, mesmo se o valor adicionado doméstico das exportações brasileiras para aquele pais tenha crescido menos do que as exportações brutas bilaterais. Isto se deve ao aumento do valor estrangeiro contido nas exportações para aquele mercado. Comparativamente aos outros dois parceiros brasileiros, o valor 
adicionado doméstico embutido nas exportações para a China atinge $89 \%$ das exportações brutas bilaterais, valor superior aqueles observados para UE e EUA ( $87 \%$ e $83 \%$, respectivamente).

$\mathrm{O}$ peso das exportações ligadas às $\mathrm{CGV}$ nas exportações brutas bilaterais é relativamente próximo para China, EUA e UE, correspondendo a cerca de $28 \%$. Esse nível é inferior ao total brasileiro, que, ao considerar o conjunto de parceiros, atinge 33\%. A América Latina e o Mercosul apresentam certamente indicadores mais elevados devido a existência de alguma articulação produtiva, notadamente no setor automotivo. Em termos de perfil da participação, UE e EUA apresentam um padrão distinto do chinês. A participação brasileira no caso das exportações com os dois parceiros mais tradicionais é do tipo para trás, com participações de valor adicionado estrangeiro nas exportações (VS) mais elevados do que no caso chinês.

Da análise setorial por parceiro comercial, o padrão observado nas exportações brutas se reproduz aqui parcialmente. Para a China, a especialização do tipo Norte-Sul fica mais evidente pelo peso e ganho de importância dos setores agrícolas e minerais nas exportações tradicionais, mas também naquelas associadas às CGV. No caso dos EUA, a indústria de transformação, apesar de ser o principal grande setor em termos de valor adicionado doméstico contido nas exportações e em termos de participação nas $\mathrm{CGV}$, demonstra um forte recuo em sua participação nas exportações totais brasileiras. Por fim, a UE apresenta um perfil intermediário, com a indústria de transformação mantendo sua posição como principal grande setor, apesar da retração relativa a 2000, porem com o setor agrícola com maior importância do que no caso dos EUA.

Dentro do setor manufatureiro, a análise mais desagregada revela que os setores com maior peso e que mais contribuíram para o crescimento das participações de VA exportado integrado a cadeias globais de valor, são setores exportadores de commodities agrícolas e industriais, como mineração, produção e abate de animais, alimentos e bebidas, metais e papel. Esse fato pode surgir como uma explicação para um limite no próprio crescimento da participação nas cadeias globais de valor. Vale ainda ressaltar que os valores agregados domésticos das exportações brasileiras em diversos setores com maior conteúdo tecnológico sofreram quedas importantes, demonstrando a queda de competitividade em relação a outros países mais ligados a CGV. Tal queda é observada também em outros setores mais tradicionais.

Portanto, com base nos resultados encontrados, pode-se dizer que o Brasil apresenta participação crescente, mas ainda assim tímida e em menor ritmo de crescimento que outras economias. A participação brasileira para frente nas CGV se destaca em relação aos outros países, por seu nível, mas também por se concentrar em exportações de bens intermediários para consumo ou produção no país de destino. Suas exportações, quando inseridas em CGV, se localizam no início das cadeias e tem vida "curta" nas mesmas - dito de outra forma, participa em geral nas chamadas CGV simples. A participação para trás é bem pequena, conforme mostrado por autores mencionados anteriores, o que se deve em grande parte a especialização comercial brasileira. A concentração das exportações em commodities agrícolas minerais, com baixo processamento industrial, explica, assim como para a Rússia, esta baixa participação para trás. 


\section{Referências}

BALDWIN, R.; Factory-free Europe? A two unbundlings perspective on Europe's twentieth-century manufacturing miracle and twenty-first-century manufacturing malaise. In: FONTAGNÉ, L.; HARRISON, A. (Eds.) The factory-free economy: Outsourcing, servitization, and the future of industry. Oxford: Oxford University Press, 2017.

CADESTIN, C.; GOURDON, J.; KOWALSKI, P. Participation in global value chains in Latin America: Implications for trade and trade-related policy. No. 192. OECD Publishing, 2016.

CAPPARIELLO, R; FELETTIGH, A. How does foreign demand activate domestic value added? A comparison among the largest euro-area economies. A Comparison Among the Largest Euro-Area Economies (January 23, 2015). Bank of Italy Temi di Discussione (Working Paper) No, v. 1001, 2015.

CASTILHO, M, Comércio internacional e a integração produtiva: uma análise dos fluxos comerciais dos países da ALADI. IPEA, Texto para discussão 1705, Brasília, 2012.

CASTILHO, M.; COSTA, K.V.; TORRACCA, J. A importância do mercado latino-americano e da competição chinesa para o desempenho recente das exportações brasileiras de produtos manufaturados. Análise Econômica, Porto Alegre, v. 37, n. 72, p. 7-38, mar. 2019.

DAUDIN, G., C. RIFFLART AND D. SCHWEISGUTH, Who produces for whom in the world economy?' Document de travail de l'OFCE N॰ 2009-18, July.

DIETZENBACHER, E. et al. The Construction of World Input-Output Tables in the WIOD Project. Economic Systems Research, 25, p. 71-98, 2013.

FERRAZ, L.; GUTIERRE, L.; CABRAL, R. A Industria Brasileira na era das Cadeias Globais de Valor. In: Nelson Barbosa; Nelson Marconi; Mauricio Pinheiro; Laura Carvalho. (Org.). Indústria e Desenvolvimento Produtivo no Brasil. 1ed.Rio de Janeiro: Elsevier, 2015, v. 1, p. 203-233.

HERMIDA, C; XAVIER, C. Competitividade internacional do Brasil à luz da fragmentação da produção e das cadeias globais de valor. Revista Brasileira de Inovação, v. 17, p. 345-376, 2018.

HUMMELS, D.; ISHII, J.; YI, K. The nature and growth of vertical specialization in world trade. Journal of international Economics, v. 54, n. 1, p. 75-96, 2001.

JOHNSON, R. C.; NOGUERA, G. Accounting for intermediates: Production sharing and trade in value added. Journal of International Economics, v. 86, n. 2, p. 224-236, 2012.

KOOPMAN, R.; WANG, Z.; WEI, S.-J. Tracing value-added and double counting in gross exports. American Economic Review, v. 104, n. 2, p. 459-94, 2014.

LEMOINE, F.; UNAL-KESENCI, D. Assembly trade and technology transfer: The case of China. World Development, 32(5), p. 829-850, 2004.

LUND, S. et al. Globalization in transition: The future of trade and value chains. McKinsey Global Institute, January, 2019.

MARCATO, M..; BALTAR, C.; SARTI, F. International competitiveness in a vertically fragmented production structure: empirical challenges and evidence. Economics Bulletin, v. 39, p. 876-893, 2019.

OECD, WTO e UNCTAD (2013) Implications of Global Value Chains for Trade, Investment and Development and Jobs. G-20 Leader Summit. Disponível em: https://unctad.org/en/PublicationsLibrary/unctad_oecd_wto_2013d1_en.pdf

COSTA, L. Inserção brasileira nas cadeias globais de valor no período entre 2000 a 2014. 2018. 157 f. Dissertação (Mestrado em Economia) - Instituto de Economia, Universidade Federal do Rio de Janeiro. 
TIMMER, M et al. The World Input-Output Database (WIOD): Contents, Sources and Methods. Working Paper 10, World Input Output Database, 2012.

TIMMER, M, et al. An Illustrated User Guide to the World Input-Output Database: The Case of Global Automotive Production. Review of International Economics, DOI:10.1111/roie.12178, 2015.

WANG, Z. WEI, S. ZHU, K. Quantifying International Production Sharing at the Bilateral and Sector Levels. USITC, 2014.

WANG, Z. et al. Measures of participation in global value chains and global business cycles. No. w23222. National Bureau of Economic Research, 2017.

WANG, Z. WEI, S. ZHU, K. Quantifying International Production Sharing at the Bilateral and Sector Levels National Bureau of Economic Research, working paper series, N. 19677, 2018.

ZACLICEVER, D. Trade integration and production sharing: A characterization of Latin American and Caribbean countries' participation in regional and global value chains. Comercio Internacional, n.137, Naciones Unidas: Comisión Económica para América Latina y el Caribe (CEPAL), 2017. 